\title{
Are predator-prey model predictions supported by empirical data? Evidence for a storm-driven shift to an alternative stable state in a crab-clam system
}

\author{
Cassandra N. Glaspie ${ }^{1,2, *}$, Rochelle D. Seitz ${ }^{1}$, Romuald N. Lipcius ${ }^{1}$ \\ ${ }^{1}$ Virginia Institute of Marine Science, William \& Mary, Gloucester Point, Virginia 23062, USA \\ ${ }^{2}$ Present address: Louisiana State University, Department of Oceanography and Coastal Sciences, Energy, Coast, \\ and Environment Building, Baton Rouge, Louisiana 70803, USA
}

\begin{abstract}
A dynamic systems approach can predict steady states in predator-prey interactions, but there are very few examples of predictions from predator-prey models conforming to empirical data. Here, we examined the evidence for the low-density steady state predicted by a LotkaVolterra model of a crab-clam predator-prey system using data from long-term monitoring, and data from a previously published field survey and field predation experiment. Changepoint analysis of time series data indicate that a shift to low density occurred for the soft-shell clam Mya arenaria in 1972, the year of Tropical Storm Agnes. A possible mechanism for the shift is that Agnes altered predator-prey dynamics between $M$. arenaria and the blue crab Callinectes sapidus, shifting from a system controlled from the bottom up by prey resources, to a system controlled from the top down by predation pressure on bivalves, which is supported by a correlation analysis of time series data. Predator-prey ordinary differential equation models with these 2 species were analyzed for steady states, and low-density steady states were similar to previously published clam densities and mortality rates, consistent with the idea that C. sapidus is a major driver of $M$. arenaria population dynamics. Relatively simple models can predict shifts to alternative stable states, as shown by agreement between model predictions (this study) and published field data in this system. The preponderance of multispecies interactions exhibiting nonlinear dynamics indicates that this may be a general phenomenon.
\end{abstract}

KEY WORDS: Mya arenaria $\cdot$ Callinectes sapidus $\cdot$ Blue crab · Soft-shell clam · Alternative stable state $\cdot$ Lotka-Volterra $\cdot$ Nonlinear dynamics $\cdot$ Chesapeake Bay

\section{INTRODUCTION}

Predators play a key role in ecosystem stability and function by consuming dominant competitors (Lubchenco \& Gaines 1981, Boudreau \& Worm 2012). Predators can also destabilize ecosystems or collapse food webs if they become too abundant (Estes et al. 2009), or if their prey do not have natural defenses against predation (Johnston et al. 2015). Except in the case of new introductions (e.g. invasive species), populations of predators and prey that have overlapping distributions have generally coevolved adapta-

${ }^{*}$ Corresponding author: cglaspie1@lsu.edu tions that allow them to coexist (Vermeij 1994). Prey have anti-predator behaviors or morphological adaptations to avoid being eaten (Bibby et al. 2007, Whitlow 2010). Similarly, predators have adaptations or behaviors that help them to forage optimally and take advantage of prey when they are available (Meire \& Ervynck 1986, Rindone \& Eggleston 2011).

One of the ways the balance between predator and prey adaptations manifests itself in nature is through density-dependent predation. Predators can exhibit a numerical response to prey densities by increasing reproduction rates due to an overabundance of prey

() The authors 2020. Open Access under Creative Commons by Attribution Licence. Use, distribution and reproduction are unrestricted. Authors and original publication must be credited. 
(demographic response) or by gathering in areas with relatively high densities of prey (aggregative response) (Holling 1959). An individual predator may also adjust its predation rate to prey density through a 'functional response' (changes in a predator's consumption rate in response to prey density). Densitydependent mechanisms tend to stabilize prey population dynamics (Royama 1992, Turchin 2003) and can maintain population viability when a population is reduced to low levels (Cushing 1975).

Certain characteristics of a predator-prey system can help predict which functional response will be observed. A linear relationship between consumption rate and prey density (Type I functional response) is expected for organisms that do not actively search for prey, such as filter feeders. Most vertebrate and invertebrate predators exhibit a hyperbolic functional response that increases to an asymptote due to limits associated with prey handling, ingestion, and metabolism (Type II functional response) (Hassell et al. 1977). Predators that feed upon cryptic or otherwise hard-to-find prey exhibit a sigmoidal functional response, where consumption rates increase slowly at low prey densities (Type III functional response) (Holling 1959). Prey that avoid predators can achieve a low-density refuge; thus, the functional response can explain the distribution of prey resources, and it can be used to predict the persistence of prey species at low densities (Eggleston et al. 1992).

Many mathematical models can be used to predict predator-prey dynamics (Briggs \& Hoopes 2004). These models contain nonlinear functions describing the density-dependent interactions between predator and prey. Due to nonlinearities, model behavior often includes shifts to alternative stable states (Drake \& Griffen 2010). The states may include extinction of one or both species, or coexistence steady states where both predator and prey are able to coexist at densities predicted by the model. Multiple stable coexistence states are possible in fairly simple predator-prey functions (Mumby et al. 2007, Kramer \& Drake 2010).

A dynamic systems approach can predict coexistence states in natural and managed systems. Steady states analysis has been used to develop optimum harvesting and conservation strategies for forest and rangeland systems (Hritonenko et al. 2013, Bauch et al. 2016). The theory surrounding steady states and bifurcations is well developed, but there are very few tests of the theory using empirical data. To date, coexistence steady states in predator-prey systems have been observed in populations of small organ- isms such as unicellular organisms, yeast, small crustaceans, and bacteria (Luckinbill 1973, van den Ende 1973, Drake \& Griffen 2010). Identifying or collecting data from coexisting predator-prey systems that can be used to test model predictions has proven difficult, especially for macro-organisms. Of the few examples of steady states that focus on macro-organisms, none examines interactions between natural populations of predators and prey (Kramer \& Drake 2010, Jiang et al. 2018, McNickle \& Evans 2018).

In this study, we examined evidence for a storm-driven shift to a low-density state for the soft-shell clam Mya arenaria, which was once a biomass-dominant species in Chesapeake Bay, USA, in the face of predation by the blue crab Callinectes sapidus. The objectives of the study were to (1) analyze over $30 \mathrm{yr}$ of $M$. arenaria and $C$. sapidus time series data for changes in abundance following a major storm event; (2) develop a Lotka-Volterra model of the crab-clam predator-prey system from parameters available in the literature and analyze for steady states; and (3) examine the agreement between model predictions and empirical data using previously published data from a field survey and a field experiment.

History of the predator-prey system. Tropical Storm Agnes, which reached and remained in the Chesapeake Bay watershed from 21 to 23 June 1972, has long been suspected of causing long-term changes to the Bay (Orth \& Moore 1983). Tropical Storm Agnes was a '100-year storm' that caused sustained, extremely low salinities and increased sedimentation throughout Chesapeake Bay (Schubel 1976, Schubel et al. 1976). This storm has been blamed for accelerating the loss of seagrass Zostera marina (Orth \& Moore 1983) and oysters Crassostrea virginica (Haven et al. 1976) in Chesapeake Bay, although these losses were already in motion before the storm occurred.

Unlike seagrass and oysters, declines in abundance of the soft-shell clam $M$. arenaria were uniquely related to the storm. $M$. arenaria was abundant enough to support a major commercial fishery throughout Chesapeake Bay prior to 1972 (Haven 1970). Widespread mass mortality of $M$. arenaria occurred after the storm (Cory \& Redding 1976), and the fishery never recovered in lower Chesapeake Bay (Virginia) (Glaspie et al. 2018). Attempts to revive a commercial fishery in Virginia waters were never realized after the passage of the storm. The commercial fishery for soft-shell clams in the Maryland portion of the Bay is characterized by variable and low harvest (Dungan et al. 2002); the fishery declined by $89 \%$ after the storm and has been near collapse since (NMFS Annual Commercial Landing Statistics, https://www.st.nmfs. 
noaa.gov/commercial-fisheries/commercial-landings/ annual-landings/index).

The failure of $M$. arenaria to recover from stormrelated declines has been attributed to predation, habitat loss, disease, rising temperatures, and overfishing (Glaspie et al. 2018). The Virginia and Maryland portions of Chesapeake Bay have different habitats, disease dynamics, climates, and fishing pressure; therefore, these factors are unlikely to explain the inability of $M$. arenaria to recover from low density in both regions (Dungan et al. 2002, Glaspie et al. 2018). More recently, disease has been blamed for an added minor decline in $M$. arenaria (Dungan et al. 2002); however, there is no evidence that disease prevalence or intensity are correlated with $M$. arenaria density (Glaspie et al. 2018).

Experimental evidence suggests that on a local scale, interactions between $M$. arenaria and its major predator, the blue crab C. sapidus (Meise \& Stehlik 2003), are capable of keeping clams at low densities (Lipcius \& Hines 1986, Seitz et al. 2001). M. arenaria burrows deeply in sediments, and although crabs can readily detect and excavate clams when they are at high densities, crabs are unable to detect their presence when clams are at low densities (Lipcius \& Hines 1986). The result is a low-density refuge for $M$. arenaria, driven by disproportionately low predation, which is characteristic of a sigmoidal functional response (Lipcius \& Hines 1986, Seitz et al. 2001). Given this evidence regarding a potential mechanism for the decline in $M$. arenaria and maintenance of the population at low density, this study examines the empirical evidence for a low-density steady state in this predator-prey system, and the impact of Tropical Storm Agnes on basin-scale population dynamics in M. arenaria.

\section{MATERIALS AND METHODS}

Changepoint analysis of time series (Killick \& Eckley 2014) was conducted using R statistical software (v. 3.6.0) on Mya arenaria landings (NMFS 2017) and log-transformed average adult female Callinectes sapidus abundance (Virginia Institute of Marine Science [VIMS] trawl survey) in the Chesapeake Bay from 1958-1992, with an Akaike's information criterion (AIC) penalty and using the segment neighbor algorithm (Auger \& Lawrence 1989). Changepoint analysis identifies the optimal number and location of changes in the mean of the data using an algorithm, in this case the segment neighbor algorithm, which produces an exact estimate of the changepoint (maximizing accuracy) at the expense of computing power (Auger \& Lawrence 1989, Killick \& Eckley 2014). The time period 1958-1992 was chosen for analysis because it begins when $M$. arenaria landings data first became available and ends before the slow decline in landings in the early 1990s due to fisheries collapse. Before and after change points, correlation between predator and prey time series was examined using cross-correlation function estimation in R. Correlation coefficients outside the $95 \%$ confidence intervals were considered evidence for temporal lags in correlation between predator and prey.

Predator-prey ordinary differential equation (ODE) models for the system including $M$. arenaria and $C$. sapidus were developed based on Lotka-Volterra models. The ODE for prey density $(N)$ was modified with a Type III functional response:

$$
N(t)=r N\left(1-\frac{N}{K}\right)-f(N) P
$$

where $N$ is the density of prey, $P$ is the density of predators, $r$ is the intrinsic per capita growth rate, $K$ is the carrying capacity, and $f(N)$ takes the form of a sigmoidal functional response:

$$
f(N)=\frac{N^{2} b T}{1+c N+b T_{h} N^{2}}
$$

where $T$ is the time available for foraging, $T_{h}$ is handling time, and $b$ and $c$ are components of the attack rate in a sigmoidal functional response (Hassell et al. 1977). The ODE model for predator density $(P)$ was considered to be unrelated to prey density, because C. sapidus are generalist predators that may feed on other species (Hines et al. 1990, Williams 1990); however, $M$. arenaria are a preferred prey item for $C$. sapidus (Blundon \& Kennedy 1982). For the purposes of this modeling effort, predator density was held constant at $P=0.06 \mathrm{~m}^{-2}$ (MD DNR Blue Crab Winter Dredge Survey, https://dnr.maryland.gov/fisheries/ Pages/blue-crab/dredge.aspx).

Models were parameterized using data from the literature as follows: $r=1.75 \mathrm{yr}^{-1}$ (Brousseau 1978), $K=$ $200 \mathrm{~m}^{-2}$ (Abraham \& Dillon 1986), $T=1 \mathrm{yr}, T_{h}=$ 0.0015 yr (Lipcius \& Hines 1986), $b=26.30 \mathrm{yr}^{-1}$ (Lipcius \& Hines 1986), and $c=0.14$ (Lipcius \& Hines 1986). Analytical solutions of steady states were calculated using Matlab statistical software. Stability of each coexistence steady state was determined by examining the sign of eigenvalues.

The clam densities predicted at stable coexistence steady states were compared to observed densities of M. arenaria in Chesapeake Bay from a published field survey (Glaspie et al. 2018). Clam mortality 
rates predicted by the ODE model were compared to mortality rates of $M$. arenaria exposed to $C$. sapidus predation in a field predation experiment (Glaspie \& Seitz 2018). To examine mortality rates, we solved the equation for number consumed:

$$
N_{E}=N-f(N) P
$$

where $N_{E}$ is the number of clams eaten calculated for a period of $8 \mathrm{~d}(0.022 \mathrm{yr})$ at an initial density of $N=$ $48 \mathrm{~m}^{-2}$ to match the field predation experiments (Glaspie \& Seitz 2018). We then calculated mortality as:

$$
M=\frac{N-N_{E}}{N} \times 100 \%
$$

where $M$ is percent mortality. Density of predators $(P)$ was allowed to vary to achieve $M=76.3 \%$ (Glaspie $\&$ Seitz 2018), and the resultant $P$ that achieved observed mortality rates of juvenile $M$. arenaria was compared to published $C$. sapidus densities for Chesapeake Bay. Data and R code files are available in the Knowledge Network for Biocomplexity repository (Glaspie 2019).

\section{RESULTS}

Changepoint analysis identified an abrupt shift in clam abundance in 1972, the year of Tropical Storm Agnes, and this was the only changepoint identified (Fig. 1). Before the storm, crab abundance was positively correlated with clam abundance at a lag of $1 \mathrm{yr}$ $(r=0.66, p=0.01$; Fig. 2a). After the storm, clam abundance was negatively correlated with crab abundance with a lag of $1 \mathrm{yr}(\mathrm{r}=-0.48, \mathrm{p}=0.04$; Fig. 2b). These were the only temporal lags for which there was evidence from cross-correlation analysis.

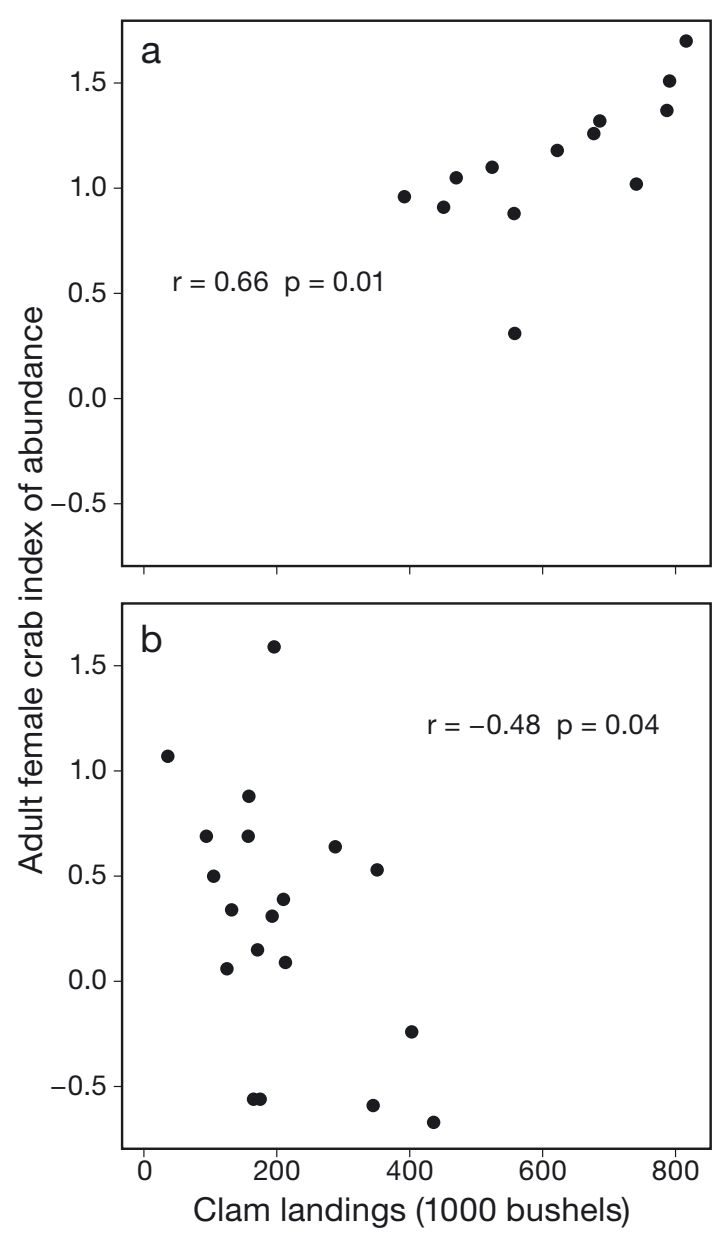

Fig. 2. Pre- and post-storm relationship between crab index of abundance (log-transformed average female abundance per tow, VIMS trawl survey) and clam landings (fisheriesdependent data). (a) Before the storm, crab abundance was positively correlated with clam abundance (1 yr lag). (b) After the storm, clam abundance was negatively correlated with crab abundance (1 yr lag)
Fig. 1. Predator-prey time series for softshell clam Mya arenaria landings (red) and adult female blue crab Callinectes sapidus index of abundance (blue). Blue crab data are log-transformed average female abundance per tow (VIMS trawl survey). M. arenaria data are fisheries landings (1000 bushels) (NMFS Annual Commercial Landing Statistics). Vertical dotted line represents Tropical Storm Agnes (1972) and the location of the changepoint from the time series analysis

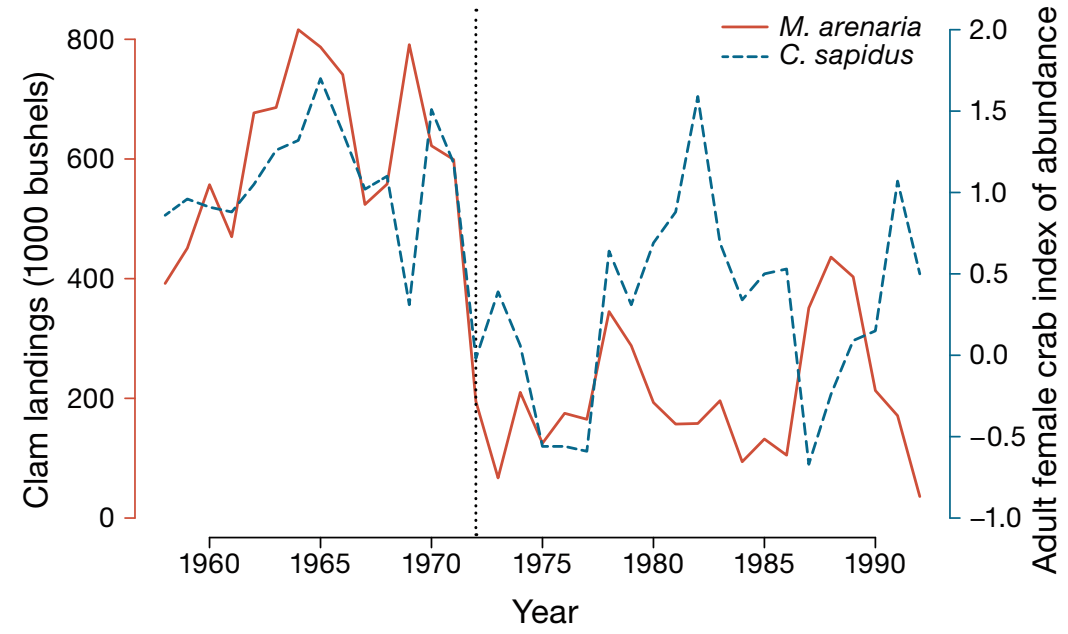


Predator-prey modeling confirmed the presence of high-density (near carrying capacity at 173.99 clams $\mathrm{m}^{-2}$ ) and low-density (at 1.41 clams $\mathrm{m}^{-2}$ ) steady states separated by an unstable steady state at 20.93 clams $\mathrm{m}^{-2}$ (Fig. 3). The low-density steady state predicted by the predator-prey model is similar to observed densities of $M$. arenaria in Chesapeake Bay, 0.4-1.73 m $\mathrm{m}^{-2}$ (95\% CI) (Glaspie et al. 2018). Mortality rates observed in the field were comparable to mortality rates predicted by the model for a blue crab density of $4.8 \mathrm{~m}^{-2}$, which is a typical density for juvenile crabs in the summer months in Chesapeake Bay (Ralph \& Lipcius 2014).

\section{DISCUSSION}

The observations, theory, and mechanistic basis indicate that Mya arenaria was subjected to a storm-driven shift to a low-density alternative stable state, which has been maintained by blue crab predation in Chesapeake Bay. Before the storm, clams were likely prey for juvenile crabs that recruited to the fishery at $1 \mathrm{yr}$ of age, resulting in a positive correlation between crab and clam abundance with a lag of 1 yr (Fig. 2a). After the storm, crabs were likely consuming juvenile clams that would have recruited to the fishery a year later, resulting in a negative correlation between clams and crab abundance with a lag of 1 yr (Fig. 2b). Both $M$. arenaria and Callinectes sapidus recruit to their respective fisheries after 1-1.5 yr (Newell \& Hidu 1986, Lipcius \& van Engel 1990), providing an explanation for the 1 yr lag. This is consistent with a shift from a system controlled from the bottom up by prey resources, to a system controlled from the top down by predation pressure on bivalves.

The results of the time series analysis would be difficult to explain with any other mechanism impacting M. arenaria population dynamics. Alternative explanations for persistent declines in $M$. arenaria density include disease, habitat loss, and environmental variability. $M$. arenaria is commonly infected by the parasitic protist Perkinsus sp., but infection intensity is not correlated with $M$. arenaria densities in Chesapeake Bay (Glaspie et al. 2018). Habitat loss in the form of declining seagrass has had a negative impact on M. arenaria (Glaspie et al. 2018) and C. sapidus alike (Anderson 1989), and would not produce the negative correlation between crabs and clams in the years after the storm. Environmental variability in particular is likely to influence population dynamics of both species, with mortality of $M$. arenaria in warm summers (Glaspie et al. 2018) and mortality of $C$. sapidus in cold winters (Rome et al. 2005). However, the effect of environmental variability is not densitydependent, and would not be expected to act differently on the 2 populations before and after the storm, as seen in this study. Predation remains the most likely explanation for the results obtained here.

Predator-prey models with these 2 species alone were capable of reproducing observations of clam densities and mortality rates, consistent with the idea that blue crabs are a major driver of $M$. arenaria population dynamics (Lipcius \& Hines 1986, Seitz et al. 2001, Meise \& Stehlik 2003). We propose that $M$. arenaria existed in Chesapeake Bay at high densities until perturbed past the unstable steady state in 1972 by Tropical Storm Agnes. Thereafter, it was able to persist at low density due to the low-



Fig. 3. Slope field diagrams for predator-prey models. Red lines indicate slope field. Trajectories of Mya arenaria density either approach a high-density stable steady state at carrying capacity (green and purple lines) or a low-density stable steady state at 1.41 clams $\mathrm{m}^{-2}$ (blue lines). Trajectories diverge from an unstable steady state at 20.93 clams m$^{-2}$ (horizontal dashed line). The solid red horizontal line at 0 represents extinction 
density refuge from blue crab predation (Lipcius \& Hines 1986, Seitz et al. 2001), rather than collapsing to local extinction. This shift to an alternative stable state is different from post-storm declines in seagrass and oysters because it is most likely maintained by density-dependent processes, specifically predation. Unfortunately, $M$. arenaria is unlikely to rebound to high abundance without a beneficial disturbance, such as a considerable recruitment episode or substantial reduction in predation pressure, which propels it above the unstable steady state and concurrently allows it to overcome the exacerbated disease burden.

Extreme weather events are costly, and they are likely to become even more common with predicted increases in the intensity and frequency of extreme events due to anthropogenic climate change (Settele et al. 2014). When examining the cost of extreme weather, ecological impacts are rarely considered, even though the impacts of such events on the ecosystem may be severe (Thomson et al. 2012). Evidence for storm-driven shifts to alternative states in coral reefs (Mumby et al. 2007), kelp ecosystems (Byrnes et al. 2011), and now soft-sediment communities (current study) suggests that management of ecosystems should include an examination of nonlinear interactions and the potential for shifts to alternative stable states.

To our knowledge, this is one of only a handful of examples of agreement between predictions from predator-prey theory and empirical data from natural systems. More evidence is needed to fully evaluate the predictive potential of steady-state analysis involving predator-prey models, and the value of a dynamics systems approach to ecosystem modeling efforts. However, the steady-state analysis approach used here can be adapted to a variety of predatorprey systems with available estimates of life history parameters, population density, and distribution. The approach may also be expanded to include more than 2 species, or encompass additional complexity, such as metabolic functions.

The concepts represented by this crab-clam predator-prey system, including population self-limitation, consumer-resource oscillations, and the functional response, are widespread in nature. These concepts may be considered 'laws' of population ecology (Turchin 2001). Each concept listed above introduces nonlinear dynamics into population models, especially those with multiple interacting species. Given the preponderance of multispecies interactions exhibiting nonlinear dynamics, multiple steady states may be a general ecological phenomenon.
Acknowledgements. We gratefully acknowledge assistance by the students and staff of the Community Ecology and Marine Conservation Biology labs at the Virginia Institute of Marine Science. This material is based upon work supported by the National Oceanic and Atmospheric Administration (grant number NA11NMF4570218), the Environmental Protection Agency EPA STAR Fellowship (grant number FP91767501), and the National Science Foundation Administration GK-12 program (grant number DGE-0840804). This paper is contribution number 3916 from the Virginia Institute of Marine Science, College of William \& Mary.

\section{LITERATURE CITED}

Abraham BJ, Dillon PL (1986) Species profiles: life histories and environmental requirements of coastal fishes and invertebrates (Mid-Atlantic) - softshell clam. US Fish Wildl Serv Biol Rep 82(11.68). US Army Corps of Engineers, TR EL-82-4. https://apps.dtic.mil/dtic/tr/fulltext/ u2/a181592.pdf

* Anderson EE (1989) Economic benefits of habitat restoration: seagrass and the Virginia hard-shell blue crab fishery. N Am J Fish Manag 9:140-149

Auger IE, Lawrence CE (1989) Algorithms for the optimal identification of segment neighborhoods. Bull Math Biol 51:39-54

Bauch CT, Sigdel R, Pharaon J, Anand M (2016) Early warning signals of regime shifts in coupled human-environment systems. Proc Natl Acad Sci USA 113:14560-14567

Bibby R, Cleall-Harding P, Rundle S, Widdicombe S, Spicer J (2007) Ocean acidification disrupts induced defences in the intertidal gastropod Littorina littorea. Biol Lett 3: 699-701

* Blundon JA, Kennedy VS (1982) Mechanical and behavioral aspects of blue crab, Callinectes sapidus (Rathbun), predation on Chesapeake Bay bivalves. J Exp Mar Biol Ecol 65:47-65

* Boudreau SA, Worm B (2012) Ecological role of large benthic decapods in marine ecosystems: a review. Mar Ecol Prog Ser 469:195-213

* Briggs CJ, Hoopes MF (2004) Stabilizing effects in spatial parasitoid-host and predator-prey models: a review. Theor Popul Biol 65:299-315

*Bousseau DJ (1978) Population dynamics of the soft-shell clam Mya arenaria. Mar Biol 50:63-71

* Byrnes JE, Reed DC, Cardinale BJ, Cavanaugh KC, Holbrook SJ, Schmitt RJ (2011) Climate-driven increases in storm frequency simplify kelp forest food webs. Glob Change Biol 17:2513-2524

Cory RL, Redding MJ (1976) Mortalities caused by Tropical Storm Agnes to clams and oysters in the Rhode River area of Chesapeake Bay. In: Anderson AM (section ed) The effects of Tropical Storm Agnes on the Chesapeake Bay estuarine system. The Johns Hopkins University Press, Baltimore, MD, p 478-487

Cushing D (1975) Marine ecology and fisheries. Cambridge University Press, New York, NY

Wrake JM, Griffen BD (2010) Early warning signals of extinction in deteriorating environments. Nature 467: 456-459

Dungan CF, Hamilton RM, Hudson KL, McCollough CB, Reece KS (2002) Two epizootic diseases in Chesapeake Bay commercial clams, Mya arenaria and Tagelus plebeius. Dis Aquat Org 50:67-78 
Eggleston DB, Lipcius RN, Hines AH (1992) Density-dependent predation by blue crabs upon infaunal clam species with contrasting distribution and abundance patterns. Mar Ecol Prog Ser 85:55-68

Estes JA, Doak DF, Springer AM, Williams TM (2009) Causes and consequences of marine mammal population declines in southwest Alaska: a food-web perspective. Philos Trans R Soc B 364:1647-1658

Glaspie CN (2019) Blue crab Callinectes sapidus and softshell clam Mya arenaria index of abundance time series 1958-1992. Knowledge Network for Biocomplexity. doi: 10.5063/F19S1PB9

Glaspie CN, Seitz RD (2018) Habitat complexity and benthic predator-prey interactions in Chesapeake Bay. PLOS ONE 13:e0205162

Glaspie CN, Seitz RD, Ogburn MB, Dungan CF, Hines AH (2018) Impacts of habitat, predators, recruitment, and disease on soft-shell clams Mya arenaria and stout razor clams Tagelus plebeius in Chesapeake Bay. Mar Ecol Prog Ser 603:117-133

Hassell MP, Lawton JH, Beddington JR (1977) Sigmoid functional responses by invertebrate predators and parasitoids. J Anim Ecol 46:249-262

Haven DS (1970) A study of the hard and soft clam resources of Virginia: annual contract report for the period 1 July 1969 through 30 June 1970. Virginia Institute of Marine Science, Gloucester Point, VA

Haven DS, Hargis WJ, Loesch JG, Whitcomb JP (1976) The effect of Tropical Storm Agnes on oysters, hard clams, soft clams, and oyster drills in Virginia. In: Anderson AM (section ed) The effects of Tropical Storm Agnes on the Chesapeake Bay estuarine system. The Johns Hopkins University Press, Baltimore, MD, p 488-508

Hines AH, Haddon AM, Wiechert LA (1990) Guild structure and foraging impact of blue crabs and epibenthic fish in a subestuary of Chesapeake Bay. Mar Ecol Prog Ser 67: 105-126

Holling C (1959) The components of predation as revealed by a study of small mammal predation of the European pine sawfly. Can Entomol 91:293-320

*Hritonenko N, Yatsenko Y, Goetz RU, Xabadia A (2013) Optimal harvesting in forestry: steady-state analysis and climate change impact. J Biol Dyn 7:41-58

Jiang J, Huang ZG, Seager TP, Lin W, Grebogi C, Hastings A, Lai YC (2018) Predicting tipping points in mutualistic networks through dimension reduction. Proc Natl Acad Sci USA 115:E639-E647

Johnston MW, Purkis SJ, Dodge RE (2015) Measuring Bahamian lionfish impacts to marine ecological services using habitat equivalency analysis. Mar Biol 162:2501-2512

Killick R, Eckley IA (2014) changepoint: an R package for changepoint analysis. J Stat Softw 58:1-19

Kramer AM, Drake JM (2010) Experimental demonstration of population extinction due to a predator-driven Allee effect. J Anim Ecol 79:633-639

Lipcius RN, Hines AH (1986) Variable functional responses of a marine predator in dissimilar homogenous microhabitats. Ecology 67:1361-1371

Lipcius RN, van Engel WA (1990) Blue crab population dynamics in Chesapeake Bay: variation in abundance (York River 1972-1988) and stock-recruit functions. Bull Mar Sci 46:180-194

Lubchenco J, Gaines SD (1981) A unified approach to marine plant-herbivore interactions. I. Populations and communities. Annu Rev Ecol Syst 12:405-437
Luckinbill L (1973) Coexistence in laboratory populations of Paramecium aurelia and its predator Didinium nasutum. Ecology 54:1320-1327

McNickle GG, Evans WD (2018) Toleration games: Compensatory growth by plants in response to enemy attack is an evolutionarily stable strategy. Ann Bot Plants 10: ply035

Meire PM, Ervynck A (1986) Are oystercatchers (Haemoptopus ostralegus) selecting the most profitable mussels (Mytilus edulis)? Anim Behav 34:1427-1435

Meise CJ, Stehlik LL (2003) Habitat use, temporal abundance variability, and diet of blue crabs from a New Jersey estuarine system. Estuaries 26:731-745

Mumby PJ, Hastings A, Edwards HJ (2007) Thresholds and the resilience of Caribbean coral reefs. Nature 450: 98-101

Newell CR, Hidu H (1986) Species profiles: life histories and environmental requirements of coastal fishes and invertebrates (North Atlantic) - softshell clam. US Fish Wildl Serv Biol Rep 82(11.53). US Army Corps of Engineers, TR EL-82-4. https://apps.dtic.mil/dtic/tr/fulltext/u2/a174837.pdf

NMFS (National Marine Fisheries Service) (2017) Fisheries economics of the United States 2015. NMFS, Washington, DC

Orth RJ, Moore KA (1983) Chesapeake Bay: an unprecedented decline in submerged aquatic vegetation. Science 222:51-53

Ralph GM, Lipcius RN (2014) Critical habitats and stock assessment: age-specific bias in the Chesapeake Bay blue crab population survey. Trans Am Fish Soc 143:889-898

* Rindone RR, Eggleston DB (2011) Predator-prey dynamics between recently established stone crabs (Menippe spp.) and oyster prey (Crassostrea virginica). J Exp Mar Biol Ecol 407:216-225

Rome MS, Young-Williams AC, Davis GR, Hines AH (2005) Linking temperature and salinity tolerance to winter mortality of Chesapeake Bay blue crabs (Callinectes sapidus). J Exp Mar Biol Ecol 319:129-145

Royama T (1992) Analytical population dynamics. Chapman \& Hall, London

Schubel JR (1976) Effects of Agnes on the suspended sediment on the Chesapeake Bay and contiguous shelf waters. In: Schubel JR (section ed) The effects of Tropical Storm Agnes on the Chesapeake Bay estuarine system. The Johns Hopkins University Press, Baltimore, MD, p 179-200

Schubel JR, Carter HH, Cronin WB (1976) Effects of Agnes on the distribution of salinity along the main axis of the Bay and in contiguous shelf waters. In: Ruzecki EP (section ed) The effects of Tropical Storm Agnes on the Chesapeake Bay estuarine system. The Johns Hopkins University Press, Baltimore, MD, p 33-65

* Seitz RD, Lipcius RN, Hines AH, Eggleston DB (2001) Density-dependent predation, habitat variations, and the persistence of marine bivalve prey. Ecology 82:2435-2451

Settele J, Scholes R, Betts R, Bunn S and others (2014) Terrestrial and inland water systems. In: Field CB, Barros VR, Dokken DJ, Mach KJ and others (eds) Climate change 2014: impacts, adaptation, and vulnerability. Part A: global and sectoral aspects. Contribution of Working Group II to the Fifth Assessment Report of the Intergovernmental Panel on Climate Change. Cambridge University Press, New York, NY, p 271-359

*Thomson JR, Bond NR, Cunningham SC, Metzeling L, Reich P, Thompson RM, Mac Nally R (2012) The influ- 
ences of climatic variation and vegetation on stream biota: lessons from the Big Dry in southeastern Australia. Glob Change Biol 18:1582-1596

Turchin P (2001) Does population ecology have general laws? Oikos 94:17-26

Turchin P (2003) Complex population dynamics. Princeton University Press, Princeton, NJ

van den Ende P (1973) Predator-prey interactions in continuous culture. Science 181:562-564

Editorial responsibility: Jean-Sébastien Lauzon-Guay, Dartmouth, Nova Scotia, Canada
Vermeij GJ (1994) The evolutionary interaction among species: selection, escalation, and coevolution. Annu Rev Ecol Syst 25:219-236

Whitlow WL (2010) Changes in survivorship, behavior, and morphology in native soft-shell clams induced by invasive green crab predators. Mar Ecol 31:418-430

Williams A (1990) Shrimps, lobsters, and crabs of the Atlantic Coast of the Eastern United States, Maine to Florida. Smithsonian Institution Press, Washington, DC

Submitted: August 12, 2019; Accepted: May 12, 2020

Proofs received from author(s): June 23, 2020 